uncontrovertible evidence, ard concludes with the remark that Shakespeare's natural history " is commonplace when it is correct, and 'Elizabethan' when it is wrong." His method of hardling animated nature has had a mcmentous fffect on all succeeding poetry, so that poctry has sung of nature on Shakespeare's lines with an extraordinary fidelity. Groups of creatures which he misrepresented bave been held up to reproach by poets since his time, and many others deserving of notice have been reglected. It is rematkrd, howerer, that "there is no necessity for a poet to te a naturalist in order to be true lo ralure; but there is the most urgent necessity that he should be in sympathy with nature and ready to acknowledge the good and beautiful, even if it should reach him in such questionable shapes as "the deadly owle' or 'a full-blown toad that venom spits." In fact, owing to the great influence of Shakespeare's writings, the peculiarities of his sympathies and antipatlies have been followed by almost all succeeding poets. His natural history was largely at fault ; indeed, the reviewer asserts that he was sadly unsymrabetic and unubservant. We conclude with a quotation which will come as a vevelation to many people: "But taking men all sotrd, ordirarily intelligent men of a country life fa town life was in Shakespeare's tay what we should now call country life), was Shakesreare, as compared with these arerage individuale, an chserver of rature?' The question is one liable to shock whose who have followed blind guides so long. The answer to it is liable to shock them more severely. No. Shakespeare was curiously unobservant of animated nature. He sefms to have seen very little. Our authority for this is his own works, which, while they abound $\mathrm{u}$ ith beauties of fancy and imagination, are most disappointing to lovers of nature by (their errors apart) their extraordinary omissions."

Four important works on marine fauna and flora form the basis of an article in the Quarterly Revitiv on "Ocean Meadows." In the course of the article, the reviewer refers to the necessity for making scientific investigations in the sea round our coasts, and shows the improbability of such work heing furthered when those who hold high offices cannot appreciate its importance. In his words :-

"The minute animal life in turn furnishes food for shoals of fishes, and the importance of an irquiry into the whole lifehistory and seasonal occurences of such organisms-the basis of the nutrition of masine life, as green plants are of terrestrial life-can scarcely be overrated. No such inquiry bas ever been conducted in a serious scientific spinit in our seas by other than private investigators, uncquipped with adequate resources for the proper study of the subject in its economic aspect. Our Fishery Boards corcern themselves as Jittle with this vital matter as they fossibly can, Nor is this apathy surprising, when it is remembered that ihe prescnt Government have ap. pointed to the chairmanship of the Scotlish Fishery Board an estimable geritleman, who possibly understards the 'branding' of herrings, but whose chief qualification for the post was a safe constituency. Yet, at the moment when this appointment was made, they had the opportunity, pressed upon them by a large body of scientific men, of choosing an eminent naluralist, whose claims as a student of the ccean are admitted by men of all nations to be univalled."

Almost every great advance in the study of the ocean has been made by this country, and though other countries are now competing with us, an opportunity will soon arise for us again to forge ahead.

"The proposed Antarctic expedition, for which a convincing case has been made out, can add to its wefulness hy taking such an investigation in hand, not only in the Southern Seas but on its way to them. There is probably no region so fertile in the forms of pelagic life as the Southern Ocean, and an expedition which should not make the study of its vegetation one of its main objects had better stay at home. There is little fear of the sul,ject being neglected in its widest aspects, since it is one of the professed 'aims which the promoters have in view,' to use the language of a prospectus. Botanists will have themselves to blame, and the public will have them to blame, if through their supine indifference this great and rich harvest of the ocean be not gathered in. In another respect the times are favourable. For many years this cuuntry lost its once eminent position in the study of the coast vegetation of the sea ; but during the last six or seven years so much good and honest work has been done by a young and energetic band of observers that this position has been in a great measure retrieved. There are not lacking among our younger botanists

No. I 28 I, VOL. 50] men of skill in the use of the most recent methods of research, capable of meeting the Germans on their own field. It will be their faul ${ }^{+}$if the naturalists of another nation forcstall them in taking possession of not the least honourable part of our empire over the sea."

In the Fortnightly", Mr. Grant Allen, in an article entitled "The Origin of Cultivation," attempts to answer the question as to bow early savages found out that plants would grow from seeds. His views are as follows:- "Cultivation began with the accidental sowing of grains upon the tumuli of the dear. Gradually it was found that by extending the dug or tilled area and sowing it all over, a crop woull grow upon it all, provided always a corpse was buried in the centre. In process of time corpses were annually provided for the purpose, and buried with great ceremony in each field. By-and-by it was found sufficient to offer up a single victim for a whole tribe or village, and to divide his body piecemeal among the fields of the community. But the crops that grew in such fields were still regarded as the direct gifts of the dead and deified victims, whose soul was supposed to animate and fertilise them. As cultivation spread, men became familiarised at last with the conception of the setd and the ploughing as the really essential elements in the proces: ; but they still continued to attach to the victim a religious im. portance, and to believe in the necessity of his presence for good luck in the harvest. With the gradual mitigation of savagery an animal saciifice was often substituted for a human one; but the fragments of the animal were still distributed through the fields with a mimic or symbolical burial, just as the fragments of the man-god had formerly been distributed. Finally, under the influence of Christianity and other civilised religions, an effigy was substituted for a human victim, though an animal sacrifice was often retained side by side with it, and a real human being was playfully killed in pantomime."

Another origin about which Mr. Grant Allen makes suggestions is that of language. His remarks on this subject appear in Longman's Magaint, under the title "The Beginnings of Speech." The Sunday Magazine contains an article on "The Stuff we are Made of," by Dr. J. MI. Hobson, in which some facts concerning amoel $x$ are stated, and also a sketch of the life and environment of Richaid Jefferies, by the Rev. B. G. Johrs. "Moon-Man or Moon-Maid" is the title of a short article by Mr. William Can'on in Good W'olds. One of Cassini's drawings of the Gulf of Rainbows on the moon shows the form of a girl's head emerging from the rocks of the promontory of Heraclides on one side of the Gulf. M. Flammarion reproduced this draxing in L'Astronomie some time ago, and lamented that he had been snable to find the figure in any other drawing, or observe it himself. A few months later, however, M. Quénesset made out the form of a man's face at the spot to which attention had been drawn, and two hours Iater on the same evening M. Mabire, observing at the Juvisy Observatory, depicted "without a single stroke of imagination" the head of a woman in the same jlace. Mr. Canton's remarks refer to these two drawinge, reproductions of which are given. The illustrations are curious, but not very instructive; they apfeal more to the poetical than the scientific mind.

Mr. Henniker Heaton writes on "Telephones : Past, Present, and Future," in the New K'evica', his point of view being cbit fly commercial. Sir Herbert Maxwell espouses the cause of tree. planting in London, and enumerates some of the trees suitable for town adornment. "The Imitative Functions, and their Place in IIuman Nature," is the theme of Mr. J. Royce in the Contury. Chambers's Fournal has several quasi-scientific zontributions, among them being articles on amber, breath. figures and dust-photogiaphs, and trees of the genus Adamsona-Cream-of.Tartar trees. In addition to the magazines named in the foregoing, we have received Scribner's, the Cont. temporary, and the Humanitarian; but none of these contain articles calling for comment here.

\section{THE SCIENCE OF VULCANOLOGY.1}

VULCANOLOGY, or the science which deals with volcanoes and related phenomena, is a very important branch of geology-ihe science which treats of the earth's crust in general. Geology is yet hardly a century old; for before that itime it consisted of little else than a collection of romantic hypotheses 1 Introductory Address to a Course of Lectcres on Vu'canology, delivered in the R. Univ. of Naples, by Dr. H. J. Johnston-Lavis. 
and incredible superstitions, This remark applies with still greater force to vulcanology, for the study of which it is necessary to posiess an extensive knowledge of physics, chemistry, and $\boldsymbol{x}$ well-developed faculty of observation. For a century or two previous to the nineteenth, however, there were acute rbservers, and we in Naples well know such names as those of Sorrentino, Duca e Padre della Torre.

Towards the end of the last century the active and extinct volcanic regions of Italy attracted the attention of four great men of science, each. of a different nationality. I allude to Spall mzani, Sir William llamilton, Dulomieu, and Breislak. Although their nationality was different, they had two merits in common - that of scientific truth and that of Baconian methods of reasoning. In other words, they were pure men of science, since by that term we understand one who observes carefully, records neither more nor leis than he observes, and draws fron these facts, and those collected by others, his conclusions, without disregard to a clear knowledge of the principles in volved, and without flights of imagination. It is, therefore, more to these four men that we owe the advance of human knowledge concerning volcanoes than to all the writers who preceded them.

In, the first years of the nineteenth century, vulcanological literature was enriched by many worker., because, as the allied sciences were then making great strides, they were able to off $\mathrm{ar}$ to vulcanologists much more powerful and accurate means of investigation. Thu; we had Humboldt, Scrope, Dubeny, Pilla, and Gemmellaro.

Following these came a phalanx of illustrious students of geolozy, some of: whom are still among us, while others, though dead in person, are living and immortal in the memory of man as heroes of science and of human knowledge. Amongst these we may enumerate Lyell, Dana, Scacchi, Palmieri, Silvestri, and Phillips, whilst at present many younger and gifted investigators are not wanting.

No other branch of science has been so heavily burdened by extravagant hypotheses, which have so much retarded its progres5, as that of vulcanology. It is not only in the first half of the present century but even still that we fiad an extensive literature produced by men who advertised themselve; as scientific investigators, when in truth they did little else but write memoirs and books to promulgate and sustain fantastic, extravagant, im ininary, and impossible hypotheses. Nevertheless, amongst this chaff we not only meet with grain, but very good grain.

$\Lambda$ s a subject of study, Vesuvius holds the first place in all vulcanological investigations of this and the last century. A few figures will make this fact more evident. Some four years since, my wife and myself collected the titles of hooks, memoirs, and other writings referring to the South Italian volcanoes, for the purpo:e of publishing a bibliographical list. We found the following numbers:-

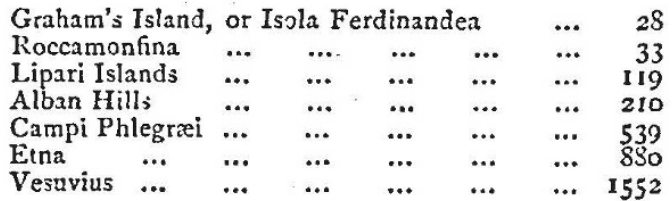

From this table it will be seen how much has been written concerning Vesuvius; in fact, its literature constitutes nearly half of what has been written about all the volcanic regions south of Rome. If we add to these the titles referring to the Campi Phlegrxi, we then find that in a total of $336 \mathrm{r}$ not less than 2091 concerns the volcanic district around Naples. Let me, however, give you a still more striking fact. The Naples branch of the Italian Alpine Club possesse; the richest vulcanological library in existence. The catalogue contains more than 7000 entries of papers, books, and manuscripts. In this number, however, are included books that not only treat of vulcanology, but in large part refer to seismology and, to a smaller extent, to geology. It will be seen, therefore, that the Neapolitan volcanic district represents more than a quarter of all vulcanolugical literature.

It is true that the history of Etna and the IE, lian Islands reach farther back than that of Vesuvius, but on the other hand the history of this Iatter is by far the most complete. From a chronological point of view, Vesuvius and also the Campi Phlegræi hold a more important place in history than any of their rivals. Even if the Pompeians, the II erculaneans and the
Stabians did lose all their proparty eighteen centuries since, the modern world has recovered it.as archas ugical.treasures, whose value represents, from the point of view of culture, many times'the original and the compound intereit on the same for the whole interval; and this we ove to our Vesuvius. The l'hlegren region around Naples is so enchained with the postry of the heroic and classic periods, that withoat it the legendr of Cuma, of Pithecusa, of Sparctacus, of Parten ope, of Baja, and so many others, which fill pages and pages of ancient history, would not exist.

Sometimes poetic ecstacy attacks the mind of the scientist; for, contrary to what the general public believe, science. rather than abolish poetic sentiment further develops it, but in a more serious and refined form.

When, as we wander around Naples, we reach the hill of Cuma, and we encounter a few ruined walls and a few potsherds that peep out through the rich vegetation of that spot, where now the only inhabitants are the goats and the lizards, our imaginations speed back for nearly three millenniums, when this same rock, almost as in its present state, was chosen by the daring Greek navigators as the site of their new colonial town. All of us know the history of Cuma, all of us know that this little bit of Italy for one half of historic time held a very im. portant place. IVe are deeply.impressed when we make an effort to conceive clearly what 3000 years really is, how many generations lived and died during that time and in that place; but far greater are we impressed when we think that 3003 years is but a fraction in the grological history of that hill, and finally our mind fails to grasp the value of time when we consider that the physical record of this hill is not more than a minute fraction of the geolorical chronology of our glo be.

Without going very far back in the geolorical history of our region, I will ask you to follow me to the first part of the Pliocene epoch, an epnch, as all know, to be considered quite near our own time. All of us now admire the beauty of the Gulf of Naples, which has few rivals in the entire world, but at that time its conformation was very different to what:it. is now. It then formed a very much larger gulf, represented to day by the plain we call the Campania Felice, with a.large part of the Terra di Lavoro. IVe must figure to ourselves a broad gulf limited on the north by the promontory of Gieta, where its confines were limited by high limestone cliffs. Its coast had roughly the following trend. From Gaeta it corresponded with the present provincial road to close under Castel. forte, and from there was almost represented by the valley of the Garigliano as far as the $\mathrm{g}$ rrge between $\mathrm{M}$ inte Faito and Monte Cammino, by which narrow strait it was in communicaion with the sea covering the plain of Cassino. IVinding round the sourh of Nonte Cammino it again extended north wards to Mignano. The eastern const of this strait corre. sponded with the present line of railway from Mignano to Taverna St. Felice, which crast, turning eastwards, passed under Presenzano to extend into the mountains by the valley of the Volturno. From this point the coast, winding round several island $=$, represented to.day by hills and mountains separnted from the main mass of the Appennines, it extended into these latter, forming so many fiords. The sea then covered all the plain, and its waves beat the foot of the mountains behind Pietramelara, Pignataro Miggiore, Capua, Caserta, Nola, Palma, Sarno, Angri, and Castellamare, and then corresponded roughly with the present coast of the peninsula of Sorrento. In the, middle of this great gulf rose two important isles-Capri and Monte Massico, besides a quantity of small ones. Numerous fiords penetrated the Appennines, where to-day we have the Crarigliano, the Volturno, Valle di Maddaloni, Valle Caudina, and the Valle di Avella. In fact, this part of the coast of Italy in those pliocene times was very similar in con* figuration to that of the Istrian coast of to.day.

The rivers bringing down to the sea sand and mud, which, settling at the bottom of the gulf, prepared an almost fiat marine Hoor, which later was to form the foundation of the Campanian Plain. At.that period the Campania Felice was only sea, and where to.day flourishes vines, oranges, lemons, and gardens of Howers, then only grew marine algr.

The great fissure in the earth's crust which corresponds. with the western coast of Italy, and along which were formed the [talian volcanoes, opened a way for the igneous magma to the bottom of this gulf. Numerous eruptive centres were formed, riving rise to the volcanoes of Ischia, Roccamonfina, Campi Phlegrrei, and Vesuvius. The order in which these different

NO. I 281 , VOL. 50] 
groups were formed is still an unsolved enigma. Ischia, as has been long known, shows by the foswiliferous deposits clothing its flanks, to have undergone great elevation since its original formation, and as we have no such evidence in the other volcanoes, we must conclude for the greater antiquity of Ischia. I also believe that the volcanic group of Roccamonfina is very much older than that of the Phlegracan Fields and Vesuvius, because we find the fiferno and the pifernozt tuff, very old volcanic deposits in these regions, forming a mantle over Roccamonfina when it was almost a complete mountain. It must not be forgotten, however, that in the "Mluseum Breccia," first de. scribed by me, we have evidence of the effusion in these regions of many varieties of rocks long an' erior to the fiferno.

Gradually the large quantity of lava and fragmentary materials that were ejected at the bottom of the guIf, greatly diminished its depth, and this, combined with general elevation, resulted in the emergence of a number of volcanic islands at Roccamonfina, Ischia, Naples; and probably Vesuvius was, at first, like the others an island. Constant general elevation soon drove back the sea, leaving high and dry all that region we so well know. This plain, with its volcanic hills and mountains, constitutes one of the most beautiful, the most fertile, and the healthiest regions of our earth, if man were more capalble of appreciating, enjoy. ing, and developing this pezzo di cielo caduto in terra.

So many are the advantages that Vesuvius offers to the student of vulcanology', that I think it advisable to pass them in review. This renowned volcano occupies a very central position in the civilised part of the globe, only a few kilometres from Naples with all the resources of a great city, and in communi. cation by numerous lines of passenger vessels and railways with all parts of Europe and America. Mleans of visiting Vesu vius are numerous, whilst the volcano is now entirely surrounded by a network of railways, besides good roads. By road and railway the top of the mountain can be reached, and upon its flanks can be found hotels and accommodation of all kinds, besides a meteorological observatory, intended to be used for the daily study and record of its varying phases. The simple but interesting form of the mountain, the extraordinary and un. rivalled variety of its productione, which surpass in number, beauty, and interest those of any other. volcano yet studied, are also a matter of maximum importance to the student. Besides this, of equal importance we must reckon that continuous activity with variation within such limits as to permit detailed study on the spot, and still more fully in the University labora. tories or elsewhere.

Scattered over Italy, and within a few hours' reach, are several other active volcanoes, each having its own special interest, besides a large number of extinct ones and subsidiary volcanic phenomena, all of which, beyond their scientific interest, have a very great importance to the inhabitants from an agricultural, industrial, and hygienic point of view. This is especially the case in the immediate vicinity of the active ones, so that it becomes the duty of the Government to maintain a system of observation and record, and to develop a school in which students may acquire a scientific knowledge of vulcanology.

At Naples we have a chair of terrestrial physics, but as under this name is included a vast amount of different groups of phenomena, it is impossible for its holder to give a fair share of vulcanology alone. So far, the only chair of valcanology was that of Catania, which was so well occupied by the late Prof $O$. Silvestri, and which, after his premature death, was abolished.

\section{UNIVERSITY AND EDUCATIONAL INTELLIGENCE.}

Oxford. - The following hase been appointed Public Examiners in the Honour School of Natural Ssience:-Mr. James Walker, of Christ Church, in Physic;, Dr. Henry F. Morley, in Chemistry, and Dr. George A. Buckmaster, of Magdalen College, in Physiology.

The list of the newly elected Fellows of the Royal Society includes three Oxford men-the Rev. F. J. Smith, Mr. V. II. Veley, and Prof. Viriamu Jones.

A conversazione will be given in the University Museum on Tuesday next, by the members of the Junior Scientific Club.

CAMrbinge. - The Board of Managers of the Arnold Gersten. berg Studentship give notice that a Studentship on this FoundaNo. 128 , voL. 50] tion will be offered for competition in the Easter Term of 1895 . Candidates will have the option of heing examined either in Logic and Methodology, or in Psychology. The Examination will be held at the time of the Moral Sciences Tripos : that is, not earlier than the last Monday but one in May 1895. The exact date of the examination will be announced Iater. The schedule of the subjects of examination will be the same as the schedules in P:ychology and in Logic and Methodology for Part I. of the Moral Sciences Tripos. The competition will be npen to men and women who have obtained honours in Part I. or Part II. of the Natural Sciences Tripos, and whose first term of residence was not earlier than the Easter Term of 1889. Candidates must send in their names not later than April 19, 1895; to Dr. Sidgwick, Newnham College, Cam. bridge, and must declare their intention, if successful, of pursuing a course of thillosophical study. The studentship, which will be of the annual value of neatly $£ 90$, will he tenable for two years, upon the condition that at the end of the first year the student's progress in philosophical study is deemed satis. factory by the Board of Managers.

Dr. W. S. Melsome, Fellow of Queen's College, and Mr. Hubert Higgine, of King's College, have been appointed Senior and Second Junior Demonstrators of Anatomy respectively.

There a:e vacancies at the University's tables in the Naples Zoological Station, and at the Plymouth Marine Biological Laboratory. Applications to occupy these are to be sent to Prof. Newton, Magdalene College, by May 24th.

Prof. Macalister announces a short course of lectures in Physical Anthropolngy for May 16th, 19th, and 21st. The subjects are "Methods of Anthropometry," "The Races of Ancient Egypt " (at this lecture a mummy will be unwrapped and examined), and "The Races of Vestern Europe."

The Council of the Senate have published a Report recommending that in future all appointments of Demonstrators, and of Assistants to Professols, shall be made for a specific period not exceeding five years. At the end of this period the Demonstrator or Assistant is to be eligible for reappointment. It is also proposed that in the case of the vacancy of a Professorship, the Demonstrators and Assistant are to cease to hold office within three months of the appointment of a new Professor.

THE Master, Wardens, and Commonalty of the Society of Merchant Venturers of the City of Bristol have decided that their Technical School shall henceforth be known as the Merchant Venturers' Technical College. In this connection the following nominations have been made:-Principal and Professor of Chemi-try, Mr. J. Wentheimer; Professor of Mechanical Engineering, Mr. J. Alunro; Professor of Electrical Engineering and Applied Physics, Mr. W. Wilson.

\section{SCIENTIFIC SERIALS.}

The Nathematical Gazette, No. I, April 1893, 8 pp. (London : Macmillan.) - It is now matter of ancient history that a correspondence in the columns of NATURE resulted in the formation, in January I87 I, of the Association for the Improvement of Geometrical Teaching. The original objects of the association were threefold : to collect and distribute information as to the prevailing methods of instruction in geometry practised in this and other countries, to use its influence to induce examining bodies to frame their questions in geometry without reference to any particular text-book, and to stamp with its approval some text-book already submitted, or to bring out a new one under its own auspices. Ten years later, viz. in January $\mathbf{1} 88 \mathbf{I}$, the association widened its basis, though after some discussion it retained its name. The objects it bad in view were now sought to be carried out by the reading of papers and raising discussions, and by the appointment of committees to report on existing defects in the usual methods, order, range, \&c., in teaching special subjects-all branches of elementary mathematics and mathematical physics being included in the widened basis. Now that the association has passed its majority, it is thought that it owes its continued existence to a " widespread desire on the part of teachers of malhematics to become acquainted with the methods of other teachers." The editor of the Gazette, Mr. E. M. Langley, to whose long-continued and enthusiastic 